\title{
Inclusive education in English foreign language classrooms
}

\author{
Rina Benko \\ rina.slivar@gmail.com \\ Elementary school Matija Petar Katančić, Valpovo
}

\author{
Anna Martinović \\ amartino@unizd.hr \\ University of Zadar
}

\begin{abstract}
This paper attempts to depict issues pertaining to inclusion in English foreign language (EFL) classes. In particular, the goal of the study was to examine the attitudes of English language teachers, pupils with special education needs (SEN), and other pupils towards inclusive English language learning in Croatian primary schools. The research was based on questionnaires taken from previously conducted research on inclusive education in Croatia and Europe. The results of this study showed generally positive attitudes towards inclusion in the English language classroom on behalf of teachers, pupils with SEN, and other pupils. However, there were some contradictory results that suggest that further research is needed. Moreover, the results point to the need for special training and education among teachers who work with special needs learners.
\end{abstract}

Keywords: inclusive education, EFL classrooms, attitudes 


\section{INTRODUCTION}

A new trend in current educational systems that has been accepted in most European countries is the inclusion of students with special educational needs (SEN) into the classroom with their peers. In this way the SEN student is included in everyday life, socializes with other children, and can feel accepted as part of a group. Inclusive education is based on the idea that every student with SEN is different and unique and should be treated as such in the educational process (Armstrong, 2012; Friend \& Bursick, 2012; Marsh, 2005). According to the guidelines for elementary school education for students with disabilities in Croatia ('Pravilnik o osnovnoškolskom odgoju i obrazovanju učenika s teškoćama u razvoju,' 2015), students with SEN ought to be completely or partially integrated into the educational process. Their educational program should be adjusted to their needs by individualizing and reducing the intensity and extensity of educational contents; moreover, their program should be enriched with specific methods, materials, and teaching aids.

Students with SEN have increasingly become a part of almost every classroom nowadays; however, there appear to be many challenges. It seems that SEN students and their learning needs and styles of learning are more often disregarded than met due to poor learning conditions, lack of material along with teachers' time deficit, or lack of knowledge which should be gained by special training (Kudek Mirošević, 2007; Padurean, 2014; Vican, 2013). Moreover, some studies suggest that SEN students are not given enough attention due to teachers' negative attitudes, and therefore are not included enough in the school programs (Bishaw \& Javaprada, 2012; Vican, 2013). The main issues which appear in the EFL classroom where SEN students are educated are: the lack of teacher training and knowledge to work with those students, teachers' attitudes, as well as inadequate curriculums and teaching methods that neglect students' abilities (Bishaw \& Javaprada, 2012). Although teacher and learner attitudes play an important role in learning success, few studies have been carried out in the Croatian context especially in regard to the inclusion of SEN learners in EFL learning.

The major aim of this paper was to investigate the attitudes of English language teachers towards learners with SEN in Croatian primary schools, the attitudes of pupils with SEN, as well as other pupils' attitudes towards special education inclusion. Firstly, the idea of inclusion will be briefly presented. Next, inclusive special education practices in Croatia will be explained through the presentation of official documents, followed by prob- 
lems found in classroom practices in Croatian primary schools. Finally, the results of the study will be presented along with a discussion of the findings.

\section{INCLUSIVE EDUCATION}

One of the greatest treasures of humankind lies in its variety of different individuals with different abilities. Accepting and acknowledging differences is one of the key principles for creating mutual respect. In the world of education, many individuals have a hard time finding their place and adjusting to the requirements of the system. The idea of inclusive education and acceptance of children with SEN is, therefore, an "educational imperative" in today's modern age (Vican \& Karamatić Brčić, 2013: 54). According to the consensus reached in Salamanca in 1994:

Every child has a fundamental right to education, and must be given the opportunity to achieve and maintain an acceptable level of learning $[. .$.$] those with special educational needs must have ac-$ cess to regular schools which should accommodate them within a child-centred pedagogy capable of meeting these needs.

(The Salamanca Statement and Framework for Action on Special Needs Education, 1994: 8)

The main problem in contemporary society and many education systems is the considerable number of students that are not "tailored to school" (Dmitrović, 2011: 72), when in fact, school is an institution that should adjust to individuals attending it. According to the definition of The Office for Standards in Education, Children's Services and Skills (OFSTED) (2000), inclusive schools are places where "the teaching and learning, achievement, attitudes and well-being of every person matter" (as cited in Hodkinson, 2010: 62). Nevertheless, the ongoing discussions about the politics and organization of SEN education are still present and the most adequate solution for students with SEN still has not been established.

A frequently asked question includes whether or not foreign language learning is necessary for students with SEN in the first place. According to Gutteridge (2003), learning a foreign language in schools is not a matter of choice anymore, but rather an obligation and desire of becoming a multicultural citizen or 'citizen of the world' in the contemporary society we live in. Furthermore, Gutteridge argues that "the prestige that English enjoys on the global stage is such that learning the language is no longer seen as op- 
tional for many people" (Gutteridge, 2003, as cited in Smith, 2006: 92), especially in the area of intercultural communication or modern technology.

Needless to say, in addition to the benefit of knowing a language other than their native language, the rewards of learning English for students with SEN are numerous. Learning any foreign language can help students with SEN develop useful skills such as cooperation with their classmates, improvement of listening and reading skills, help them learn how to express themselves or in the end, just to work on their creativity. As the European Commission (2005) concluded, social and personal development are goals that can be achieved by learning a foreign language, and success reaches beyond communicative competence. Moreover, the reason for learning a language may not only be for the sake of actually mastering the language, but can serve as a tool for personal development (as cited in McColl, 2005).

It is evident that teaching personnel and their attitudes towards students with SEN have a significantly important role in the promotion of inclusion. Processes of change in education cannot begin with negative attitudes and resistance towards it. By their definition, attitudes are an important part of our everyday life as they have a major impact on our behavior, making certain actions predictable (Borić \& Tomić, 2012). In order to accept the idea of inclusion, it is necessary to initially change existing attitudes towards students and people with disabilities in society, as well as to accept differences and individual distinctions beyond the level of mere respect or tolerance (Borić \& Tomić, 2012).

\section{INCLUSIVE SPECIAL EDUCATION IN CROATIA}

The World Conference on Education for All in the year 1990 adduced six objectives as a guide for inclusion politics: "to improve the educational system for early childhood, to enable free elementary education for all, to ensure quality learning and gaining competences for future life, to increase literacy rate, to eliminate discrimination and to ensure quality education for every child" (as cited in Vican \& Karamatić Brčić, 2013: 50). In addition, the freedom to regulate and elaborate these goals in educational practices was left to the policies of each individual country.

\subsection{Legal framework of inclusion in Croatia}

The process of integration of pupils with learning abilities in elementary schools in Croatia did not begin until 1980, when official documents were put into effect. However, inclusive education is still not regulated with any 
specific act, but it is documented in the Act on Primary Education and Regulations on Primary Education of Students with Developmental Handicaps (2017), as well as in some other regulations and acts, but to a considerably smaller extent.

According to the Act on Education in Primary and Secondary Schools (2017), before regular registration in the first grade of primary school, the psychophysical condition of each child is to be determined in order to define the appropriate education. According to the previously mentioned regulations, inclusive teaching for pupils with disabilities in mainstream classes in Croatian schools operates on two levels, firstly, a regular program with individualization, and secondly, a regular program with adjustment of content and individualization. The regular program with individualization is designed for the students who are, according to their difficulties, able to follow the curriculum without limitation of content but require a certain amount of support from teachers. Moreover, individualization can be determined for one or more school subjects and it is guided by the teacher in the mainstream classroom. In addition, the program for each child is to be made individually by the teacher in cooperation with expert associates and the parents of a child.

The regular program with adjustment of content and individualization is, on the other hand, designed for pupils who are unable to cope with the curriculum without the limitation of content and who need an individual approach according to the nature of their disability. In addition, the reduction of content is allowed to be decreased ranging from one subject to all school subjects, as well as to the lowest possible level of acquisition of educational requirements legitimated by the curriculum. Special education with individualization is also regulated in Croatian schools, but it is designed for pupils who are unable to follow regular programs, but who must attend special classes. However, a student does not necessarily spend all of their school time in a special classroom, but rather he or she can also attend the mainstream program in some subjects, with reduction of content or individualization, if he or she is determined by specialists to be capable of it.

\subsection{Issues concerning inclusive education in Croatia}

The legislation and regulation policy on inclusion in Croatia is worth praising, however, it appears that there are some problems in implementing these policies in practice. The administration of a particular issue is rarely implemented and it seems that inclusive policy in education is an excep- 
tion more often than a rule. For example, Vican (2013: 23-24) states that "laws, regulations and pedagogical standards do not create inclusive school culture in any education system, nor will it in ours, and the area between school politics and practice is often considerably distant." Even though significant efforts have been made to improve education in Croatia in the past few years, such as the creation of The Croatian National Educational Standard in 2005, which was drafted in an attempt to develop schools that are tailored to students and not vice versa, the realization has failed in many aspects (Kudek Mirošević, 2007).

According to a report concerning the inclusive education situation in Croatia (OECD, 2007), some of the main reasons for not implementing regulations are a lack of resources, a lack of understanding from society, as well as disrespect towards individuals with SEN. Furthermore, classes often contain a larger number of pupils than allowed, there is a lack of experts in the field of special education, along with the existing problem of inadequacy of certain teachers (OECD, 2007). Moreover, Bouillet (2013: 98) has stated that the law in Croatia respects the modern approach to inclusion, but the proper implementation fails due to "inadequate material conditions and lack of professional support to teachers (school counselors, assistants, etc.)" as well as the problematic attitudes of teachers. Also, the detection of SEN pupils seems to be failing as well, since only 3 percent of such pupils are evidenced in practice, while 10 percent of such individuals are to be expected in schools (Igrić, 2003).

\subsection{Previous research conducted in Croatia}

Earlier research (Kiš-Glavaš, Nikolić \& Igrić, 1997) pointed out relatively negative attitudes towards children with SEN and integration in general. Even though teachers reported that SEN pupils impersonate encumbrance for them in the classroom, they perceived them as relatively safe for the rest of the pupils, since they did not seem to negatively affect the behavior or success of the rest of the class (Kiš-Glavaš, Nikolić \& Igrić, 1997). A more recent report of the educational system in Croatia (Bouillet, 2013: 110) demonstrated an equal number of full and conditional support of inclusion by teachers, meaning that those who support inclusion only conditionally believed that the education system is not ready for "the diversity that inclusion brings to classes," while only a small number rejected the idea of inclusion. 
According to Igrić (2012), pupils with disabilities are often perceived as lazy and naughty and are regularly punished due to their failure in school, even though their poor results are a matter of an objective disability. These situations, frequent in Croatian schools, help motivate negative attitudes among teachers, while it is evident that teachers lack prerequisite knowledge and experience in teaching, which results in creating a poor image of SEN students. More often than not, SEN learners are not involved in the lesson - while being physically present, their thoughts and attention might be elsewhere. For that reason, it is important to emphasize that participation alone and access to education are not sufficient; in other words, the SEN learner must be holistically involved in the process of learning (Watkins, 2009).

Other research conducted in Croatia concluded that the inadequate education of teachers in terms of dealing with SEN is presumably the basis of the problem concerning negative attitudes (Kiš-Glavaš, Nikolić, \& Igrić, 1997). The teachers in this study reported being overburdened with the workload and large classes, as well as frustrated with the lack of didactic material and strictly prescribed curricula (Kiš-Glavaš, Nikolić \& Igrić, 1997). Similarly, according to more recent research (Bukvić, 2014), the majority of the examinees reported having little or no knowledge about teaching students with SEN. Consequently, a great number of teachers strongly agreed with the claim that they needed to learn more about students with intellectual difficulties and needed to develop new strategies in approaching them (Bukvić, 2014).

Recently, a study concerning teachers' attitudes towards inclusion pointed out teachers' agreement with the ideas that inclusion helps learners to develop independence and that it is unethical to separate students with SEN in special classes (Skočić Mihić, Gabrić \& Bošković, 2016). In the same study, teachers agreed that including students with disabilities contributed to the development of other students in the class, as well as students with SEN. Vican (2013) showed that younger pupils tend to have a more positive attitude towards inclusion compared to older pupils. The author suggested that this might have resulted from the fact that their workload is significantly reduced, and that they have only one teacher who is more familiar with the pupils with SEN in the classroom. Also, considering the geographical variable, Vican (2013) found that learners from small towns in areas of Slavonija, Lika, and Banovina perceived inclusion in their schools more positively than pupils from Zagreb which could be explained by the 
fact that pupils tend to be more connected and closer in smaller towns than in larger cities.

Another important aspect regarding inclusive education that needs to be taken into account is the attitudes of other students towards students with SEN. Two studies conducted in Croatia (Igrić, Jakab \& Cvitković, 2012; Žic \& Igrić, 2001) showed mainly negative attitudes towards pupils with SEN. Firstly, Igrić, Jakab, and Cvitković (2012) found that attitudes towards children with disabilities were unfavorable from the side of the teachers, as well as from the side of their classmates, who perceived them as less desirable and often rejected them in social activities. As a result, the authors in this study concluded that real inclusion failed in many classrooms since children were not involved in-class activities (Igrić, Jakab \& Cvitković, 2012). Secondly, a study carried out by Žic and Igrić (2001) showed analogous results. Similarly, it was noted that children with intellectual difficulties were mainly rejected by their classmates since the number of pupils who were willing to study, sit or play with them was considerably small (Žic \& Igrić, 2001). However, pupils with SEN marked relationships with their classmates as satisfying (Žic \& Igrić, 2001).

\section{AIM AND METHOD}

In this research, the attitudes of English FL teachers, pupils with SEN, and other pupils in the inclusive classroom were investigated. Since they all are direct participants in the inclusive classroom, and if we wish to get a realistic picture of the process and practice of inclusive education, we need to evaluate their attitudes equally. In this research, the term SEN is used only for pupils with intellectual difficulties, since they were the target group for this research.

\subsection{Aim}

The major aim of this research was to investigate English FL teachers' attitudes towards teaching pupils with SEN, as well as pupils' attitudes toward inclusion in the English language classroom. In particular, the study focused on participants' views regarding the extent to which English language classrooms are inclusive. The research attempted to answer the following research questions:

1) What are teachers' attitudes toward teaching English to SEN students?

2) What are SEN pupils' attitudes toward learning English?

3) What are other pupils' attitudes toward pupils with SEN in the EFL classroom? 


\subsection{Method}

\subsubsection{Sample}

Participants in this research were from five elementary schools in Croatia, specifically, from the Osječko-baranjska county in the Slavonian region. The sample included: 15 English teachers aged between 27 and $50(\mathrm{M}=$ $39.5, \mathrm{SD}=6.25), 25$ pupils with intellectual difficulties aged between 10 and $15(\mathrm{M}=11.52, \mathrm{SD}=1.36)$ who attended English lessons, and 53 other pupils aged between 9 and $15(\mathrm{M}=11.40, \mathrm{SD}=1.39)$.

\subsubsection{Instruments, procedures, and data analysis}

Three different questionnaires were used in this research, including a questionnaire for teachers, a questionnaire for pupils with SEN, and a questionnaire for pupils who attended the classroom with pupils with disabilities. The questionnaires were based on a three-point Likert scale with possible answers ranging from 1 (agree), 2 (partially agree), and 3 (disagree). The questionnaires asked for gender and age information. The questionnaires entailed 29 questions for teachers, 19 questions for pupils with SEN, and 18 questions for other pupils who attended classes with SEN pupils. They were adapted from several questionnaires, including the questionnaire Moja osnovna škola (Vican, 2013), the questionnaire found in the article Teaching English Language to Children with Special Educational Needs (Padueran, 2014), and questionnaire from the article Inclusive education of pupils with special educational needs in Czech Republic primary schools (Bendová \& Fialová, 2015). The language of the questionnaire was Croatian. Signed letters of consent were obtained from the principals of the schools and parents. Pupils were informed that their participation was voluntary and anonymous. Completion of the questionnaire took place during regular English classes. Descriptive analysis of the data was carried out including frequencies for each of the respective statements since only a three-point Likert scale was used indicating agreement or disagreement.

\section{RESULTS}

In this section the results of the research are presented beginning with teacher attitudes towards inclusive FL classrooms, followed by the attitudes of pupils with SEN towards learning English, as well as attitudes of pupils who take English FL classes together with pupils with SEN. Upon careful study of the responses, several categories emerged which provided a frame- 
work for the analysis. The categories included: 1 . Inclusion of pupils with SEN in the learning process; 2 . Attitudes towards teacher engagement of pupils with SEN in the learning process; 3 . General attitudes towards pupils with SEN in the classroom; 4. Acceptance of pupils with SEN in classroom activities. In addition, the teacher questionnaire included the following category: Attitudes towards teacher competency in teaching pupils with SEN.

\subsection{Teachers' attitudes}

\subsubsection{Teacher attitudes towards inclusion in the learning process}

The results of the study showed that teachers regularly endeavor to include pupils with SEN in their English classes, with $67.7 \%$ of the teachers agreeing with this statement and $33.3 \%$ partially agreeing with it. Moreover, most teachers $(66.7 \%)$ partially agreed with the statement that they regularly call on pupils with SEN to include them in the classroom activities, while a minority of teachers $(26.7 \%)$ completely agreed and only one teacher disagreed. Furthermore, most teachers (60\%) stated that pupils with SEN are often involved in pair or group work in their lessons, while $33.3 \%$ partially agreed.

\subsubsection{Teacher engagement in the learning process of pupils with SEN}

When it comes to creating special activities and assignments for pupils with SEN, the majority of teachers (73.3\%) only partially agreed that they designed different activities for pupils with intellectual difficulties in their classroom, while only one disagreed. Moreover, $86.7 \%$ of the teachers agreed that they encourage pupils with SEN to address them in case they felt excluded in their lectures. Additionally, all the teachers confirmed that they never excluded pupils with intellectual difficulties during their lessons and regularly motivated them to fully participate in the classroom activities. A majority of the teachers (60\%) stated that they endeavored to present the curriculum in the best possible way to pupils with SEN, while $40 \%$ of them only partially agreed. Moreover, all the teachers agreed with the statement I always do my best to offer a comprehensible explanation to a SEN pupil when asked. Also, a great number of the examinees (80\%) stated that they were willing to assist their pupils in their learning process, while a minority $(20 \%)$ only partially agreed. Similarly, $80 \%$ of the teachers declared that they motivated other pupils in the class to assist pupils with intellectual difficulties during the lesson, while 20\% partially agreed. With regard to the statement that they were familiar with the family situation 
of pupils with SEN and regularly cooperated with their parents, a great number of teachers partially agreed (73.3\%). Finally, a majority of teachers (60\%) declared that they strived to encourage inclusion in their classroom, while the rest of the teachers agreed only partially (40\%). The results are shown in Table 1.

Table 1. Teacher engagement in the learning process of pupils with SEN

\begin{tabular}{|c|c|c|c|c|c|}
\hline $\begin{array}{l}\text { ITEM } \\
\text { No. }\end{array}$ & QUESTION & $\mathbf{N}$ & $\begin{array}{l}\text { AGREE } \\
\text { (\%) }\end{array}$ & $\begin{array}{l}\text { PARTIALLY } \\
\text { AGREE (\%) }\end{array}$ & $\begin{array}{l}\text { DISAGREE } \\
\text { (\%) }\end{array}$ \\
\hline 4 & $\begin{array}{l}\text { I often come up with special and interesting } \\
\text { tasks and activities for students with } \\
\text { intellectual disabilities. }\end{array}$ & 15 & 20 & 73.3 & 6.7 \\
\hline 6 & $\begin{array}{l}\text { I assure students with intellectual disabilities } \\
\text { that they can always contact me if they feel } \\
\text { unhappy or excluded. }\end{array}$ & 15 & 86.7 & 13.3 & / \\
\hline 8 & $\begin{array}{l}\text { I never exclude students with intellectual } \\
\text { disabilities, and I try to motivate them to } \\
\text { participate in class. }\end{array}$ & 15 & 100 & / & / \\
\hline 12 & $\begin{array}{l}\text { I always try to present new material in a way } \\
\text { that students with intellectual disabilities can } \\
\text { best understand. }\end{array}$ & 15 & 60 & 40 & / \\
\hline 16 & $\begin{array}{l}\text { When a student with intellectual disabilities } \\
\text { asks me for an explanation, I always try to offer } \\
\text { the best possible explanation. }\end{array}$ & 15 & 100 & / & / \\
\hline 18 & $\begin{array}{l}\text { I am happy to help a student with intellectual } \\
\text { disabilities. }\end{array}$ & 15 & 80 & 20 & / \\
\hline 19. & $\begin{array}{l}\text { I motivate other students in the class to help } \\
\text { students with intellectual disabilities. }\end{array}$ & 15 & 80 & 20 & / \\
\hline 21 & $\begin{array}{l}\text { I often work with the parents of students with } \\
\text { intellectual disabilities and I am familiar with } \\
\text { their situation. }\end{array}$ & 15 & 13.3 & 73.3 & 13.3 \\
\hline 22 & $\begin{array}{l}\text { I do my best to encourage inclusion in the } \\
\text { classroom. }\end{array}$ & 15 & 60 & 40 & / \\
\hline
\end{tabular}

\subsubsection{General teacher attitudes towards pupils with SEN}

When it comes to teacher attitudes on the benefits of the English lesson for SEN pupils, the same number of examinees agreed (40\%) and partially agreed (40\%) that English lessons were too difficult for pupils with SEN to comprehend. Although a large number $(46.7 \%)$ of the teachers declared that they did not find it problematic to teach learners with intellectual difficulties; nevertheless, 33\% only partially agreed with this statement. Furthermore, the majority of teachers $(60 \%)$ partially agreed with the state- 
ment that learners with intellectual difficulties could comprehend and learn, as well as successfully fulfill requirements of the class, while a minority (33.3\%) disagreed. With regard to the question of whether pupils with SEN would be better off learning English in another setting, $46.7 \%$ of the teachers partially agreed, while $40 \%$ of the teachers agreed completely with this statement. All of the teachers stated that they felt pleased when they noted advancement in the learning process of their SEN pupils. Regarding the issue of whether or not learners with difficulties often disturbed English lessons, $60 \%$ of the teacher partially agreed with $40 \%$ disagreeing with this statement. More than half of the examinees (53.3\%) reported that inclusive education is useful for pupils with SEN; however, the majority of teachers (73.3\%) also agreed that they needed a significant amount of time to prepare a lesson and adjust English lecture to the needs of all the students. The results are shown in Table 2.

Table 2. General teacher attitudes towards pupils with SEN

\begin{tabular}{|c|c|c|c|c|c|}
\hline $\begin{array}{l}\text { ITEM } \\
\text { No. }\end{array}$ & QUESTION & $\mathbf{N}$ & $\begin{array}{l}\text { AGREE } \\
(\%)\end{array}$ & $\begin{array}{l}\text { PARTIALLY } \\
\text { AGREE (\%) }\end{array}$ & $\begin{array}{l}\text { DISAGREE } \\
\text { (\%) }\end{array}$ \\
\hline 5 & $\begin{array}{l}\text { I think the English lesson is too difficult for } \\
\text { students with disabilities. }\end{array}$ & 15 & 40 & 40 & 20 \\
\hline 9 & $\begin{array}{l}\text { It is not a problem for me to teach students } \\
\text { with intellectual disabilities. }\end{array}$ & 15 & 46.7 & 33.3 & 20 \\
\hline 13 & $\begin{array}{l}\text { I think students with intellectual disabilities } \\
\text { understand the content in English language } \\
\text { classes and can learn what is required of them. }\end{array}$ & 15 & 6.7 & 60 & 33.3 \\
\hline 15 & $\begin{array}{l}\text { I think it would be better for students with } \\
\text { disabilities to learn English in a different } \\
\text { environment. }\end{array}$ & 15 & 40 & 46.7 & 13.3 \\
\hline 20 & $\begin{array}{l}\text { I feel happy and satisfied when I notice } \\
\text { progress in learning English among students } \\
\text { with disabilities. }\end{array}$ & 15 & 100 & / & / \\
\hline 24 & $\begin{array}{l}\text { I think students with disabilities often disrupt } \\
\text { the English lesson. }\end{array}$ & 15 & / & 60 & 40 \\
\hline 27 & $\begin{array}{l}\text { I think inclusive education is beneficial for } \\
\text { students with disabilities. }\end{array}$ & 15 & 53.3 & 40 & 6.7 \\
\hline 29 & $\begin{array}{l}\text { In teaching students with disabilities, it was } \\
\text { necessary to spend a lot of time to create } \\
\text { a special syllabus and to change regular } \\
\text { classroom practices. }\end{array}$ & 15 & 73.3 & 26.7 & / \\
\hline
\end{tabular}




\subsubsection{Acceptance of pupils with SEN in classroom activities}

Most of the teachers (66.7\%) agreed that other learners accepted pupils with SEN as a part of the group and cooperated with them, while a smaller number of teachers partially agreed (26.7\%). Furthermore, a large majority (86.7\%) disagreed with the statement that learners with intellectual difficulties often disturbed the English lesson and that lessons would be better without them. Also, more than half of the teachers who participated in the study (53.3\%) partially agreed that they would not choose to teach in a classattended by pupils with SEN while a fewer number (40\%) disagreed. Additionally, a great number of teachers (80\%) stated that they did not differentiate among learners in their class, while a minority (20\%) partially agreed. All the teachers agreed that they accepted learners with intellectual difficulties as a part of the classroom group. Also, a majority of teachers (93.3\%) declared that they were pleased to hear ideas from pupils with SEN during their lessons. The results can be seen in Table 3.

Table 3. Teacher attitudes towards acceptance of pupils with SEN in classroom activities

\begin{tabular}{l|l|c|c|c|c}
\hline $\begin{array}{l}\text { ITEM } \\
\text { No. }\end{array}$ & QUESTION & N & $\begin{array}{c}\text { AGREE } \\
\%\end{array}$ & $\begin{array}{c}\text { PARTIALLY } \\
\text { AGREE } \%\end{array}$ & $\begin{array}{c}\text { DISAGREE } \\
\%\end{array}$ \\
\hline 7 & $\begin{array}{l}\text { Other students in my class accept students with } \\
\text { intellectual disabilities as part of the group and } \\
\text { collaborate with them. }\end{array}$ & 15 & 66.7 & 26.7 & 6.7 \\
\hline 10 & $\begin{array}{l}\text { I think students with disabilities disrupt English } \\
\text { lessons and I would be happier if I didn't have } \\
\text { to teach them. }\end{array}$ & 15 & $/$ & 13.3 & 86.7 \\
\hline 11 & $\begin{array}{l}\text { If I could, I would not choose to teach in a class } \\
\text { with students with intellectual disabilities. }\end{array}$ & 15 & 6.7 & 53.3 & 40 \\
\hline 14 & $\begin{array}{l}\text { I don't differentiate between my students in } \\
\text { class. }\end{array}$ & 15 & 80 & 20 & $/$ \\
\hline 17 & $\begin{array}{l}\text { I accept students with intellectual disabilities as } \\
\text { part of the class. }\end{array}$ & 15 & 100 & $/$ & $/$ \\
\hline 23 & $\begin{array}{l}\text { I am happy to listen to the ideas expressed by } \\
\text { students with intellectual disabilities. }\end{array}$ & 15 & 93.3 & 6.7 & $/$ \\
\hline
\end{tabular}

\subsubsection{Teacher competency in teaching pupils with SEN}

Concerning teacher competency regarding their ability to recognize the educational needs of learners with intellectual difficulties, most of the teachers $(73.3 \%)$ only partially confirmed that they felt competent enough, while $13.3 \%$ disagreed. Furthermore, all the teachers agreed that they needed further education when it comes to language teaching pupils with SEN. 
Finally, teachers were divided about their ability to plan a lesson for a heterogeneous group of EFL learners with $40 \%$ agreeing with this statement and $46.7 \%$ partially agreeing.

\subsection{Attitudes of pupils with SEN}

\subsubsection{Inclusion in the learning process}

To begin with, most of the pupils with SEN (72\%) stated that they felt included in the English lesson. With regard to participation in the English language lesson, SEN pupils were split between agreeing (44\%) that teacher included them in the activities of the class by calling on them, while $36 \%$ partially agreed with this statement. This was similar to the result concerning the topic of their participation in pair or group work with other pupils in the English class, with 48\% agreeing and 36\% partially agreeing with this statement.

\subsubsection{Teacher engagement in the learning process of pupils with SEN}

A large number of pupils with SEN either agreed (36\%) or partially agreed (20\%), while $40 \%$ disagreed with the statement that the teacher often created interesting and special assignments for them. Moreover, $60 \%$ of pupils with SEN reported that they felt comfortable addressing their English teacher in case they felt excluded or dissatisfied. Also, 76\% of the pupils with SEN stated that their English teacher always assisted them if they misunderstood some aspect of the lecture. The results are shown in Table 4.

Table 4. Pupils with SEN: Attitudes towards teacher engagement in their learning process

\begin{tabular}{l|l|c|c|c|c}
\hline $\begin{array}{l}\text { ITEM } \\
\text { No. }\end{array}$ & QUESTION & $\mathbf{N}$ & $\begin{array}{c}\text { AGREE } \\
\text { (\%) }\end{array}$ & $\begin{array}{c}\text { PARTIALLY } \\
\text { AGREE (\%) }\end{array}$ & $\begin{array}{c}\text { DISAGREE } \\
\text { (\%) }\end{array}$ \\
\hline 4 & $\begin{array}{l}\text { The teacher often gives me special and } \\
\text { interesting assignments. }\end{array}$ & 24 & 36 & 20 & 40 \\
\hline 6 & $\begin{array}{l}\text { If I feel unhappy, I can always turn to my English } \\
\text { teacher. }\end{array}$ & 25 & 60 & 32 & 8 \\
\hline 15 & $\begin{array}{l}\text { When I don't understand something, the } \\
\text { English teacher always helps me. }\end{array}$ & 25 & 76 & 16 & 8 \\
\hline
\end{tabular}

\subsubsection{General attitudes of pupils with SEN}

Most pupils with SEN (70.8\%) stated that they liked learning English in school, and 64\% of them declared they found the English lesson interesting. Moreover, a majority of SEN pupils (72\%) reported they would choose to 
participate in an English language class again. In addition, 60\% of pupils with SEN stated they looked forward to English lessons, while 24\% partially agreed. Also, most pupils with SEN (91.7\%) declared they felt satisfied every time they succeeded in fulfilling a particular task. However, a third (33.3\%) of the pupils with SEN reported they found the English lesson too difficult to understand, while $58.3 \%$ of them disagreed. Furthermore, a large number of SEN pupils (48\%) stated they understood the curriculum taught during an English language lesson, while 40\% of pupils agreed partially. Most of the pupils with SEN (60\%), stated that they did not think it would be better for them to learn English in a smaller group, while 24\% of the pupils agreed with this statement. The results are presented below.

Table 5. General attitudes of pupils with SEN towards learning English

\begin{tabular}{l|l|c|c|c|c}
\hline $\begin{array}{l}\text { ITEM } \\
\text { No. }\end{array}$ & QUESTION & $\mathbf{N}$ & $\begin{array}{c}\text { AGREE } \\
\text { (\%) }\end{array}$ & $\begin{array}{c}\text { PARTIALLY } \\
\text { AGREE (\%) }\end{array}$ & $\begin{array}{c}\text { DISAGREE } \\
\text { (\%) }\end{array}$ \\
\hline 5 & I think the English lesson is too difficult for me. & 24 & 33.3 & 8.3 & 58.3 \\
\hline 9 & $\begin{array}{l}\text { I like learning English at school, even though } \\
\text { some students are better than me. }\end{array}$ & 24 & 70.8 & 16.7 & 12.5 \\
\hline 10 & I think learning English is interesting. & 25 & 64 & 20 & 16 \\
\hline 11 & $\begin{array}{l}\text { If I could, I would choose to learn English at } \\
\text { school again. }\end{array}$ & 25 & 72 & 20 & 8 \\
\hline 12 & $\begin{array}{l}\text { I understand the material and can follow } \\
\text { English lessons. }\end{array}$ & 25 & 48 & 40 & 12 \\
\hline 13 & $\begin{array}{l}\text { I think it would be better for me to learn English } \\
\text { in a smaller group than in class with other } \\
\text { pupils. }\end{array}$ & 25 & 24 & 16 & 60 \\
\hline 16 & $\begin{array}{l}\text { I always feel satisfied when I manage to } \\
\text { correctly complete a task in English. }\end{array}$ & 24 & 91.7 & 8.3 & / \\
\hline 17 & I look forward to learning English. & 25 & 60 & 24 & 16 \\
\hline
\end{tabular}

\subsubsection{Acceptance of pupils with SEN in classroom activities}

A majority of pupils with SEN (68\%) stated that they felt part of the English class, while $28 \%$ partially agreed. Moreover, $50 \%$ of the pupils with SEN declared they did not feel excluded by the other pupils in class during the English lesson, while 33.3\% disagreed. Furthermore, most pupils with SEN (72\%) stated that their classmates regularly helped them understand a lesson when asked, and $56 \%$ of them stated that the teacher was always pleased to hear their ideas during the lesson. Additionally, a majority of pupils with SEN (76\%) reported satisfaction due to frequent socialization with their peers in school. The results are shown in Table 6 below. 
Table 6. Acceptance of pupils with SEN in classroom activities

\begin{tabular}{l|l|c|c|c|c}
\hline $\begin{array}{l}\text { ITEM } \\
\text { No. }\end{array}$ & QUESTION & $\mathbf{N}$ & $\begin{array}{c}\text { AGREE } \\
\text { (\%) }\end{array}$ & $\begin{array}{c}\text { PARTIALLY } \\
\text { AGREE (\%) }\end{array}$ & $\begin{array}{c}\text { DISAGREE } \\
\text { (\%) }\end{array}$ \\
\hline 7 & $\begin{array}{l}\text { I feel like a part of the class during English } \\
\text { lessons. }\end{array}$ & 25 & 68 & 28 & 4 \\
\hline 8 & $\begin{array}{l}\text { I don't feel that other pupils exclude me in } \\
\text { English classes. }\end{array}$ & 24 & 50 & 16.7 & 33.3 \\
\hline 14 & $\begin{array}{l}\text { When I don't understand something, my } \\
\text { classmates help me with English. }\end{array}$ & 25 & 72 & 16 & 12 \\
\hline 18 & $\begin{array}{l}\text { The English teacher is always happy to listen to } \\
\text { my ideas in class. }\end{array}$ & 25 & 56 & 36 & 8 \\
\hline 19 & $\begin{array}{l}\text { I often hang out with my classmates and this } \\
\text { makes me happy. }\end{array}$ & 25 & 76 & 8 & 16 \\
\hline
\end{tabular}

\subsection{Attitudes of pupils taking English classes with pupils with SEN}

\subsubsection{Inclusion of pupils with SEN in the learning process}

Most of the pupils who took English classes with pupils with SEN (63.5\%) stated that they felt that pupils with SEN were included in an English lesson in their school. However, when asked whether the English teacher often called on pupils with SEN during the lessons many regular pupils (43.4\%) stated that they disagreed with the statement, while $41.5 \%$ of the pupils partially agreed. Furthermore, pupils were divided concerning the question of whether pupils with SEN often worked in pair or group with the rest of the class in an English lesson, with $47.2 \%$ agreeing, 20.8\% partially agreeing, and 32.1\% disagreeing. Also, many other pupils who attended English lessons together with SEN pupils $(40.4 \%)$ partially agreed with the statement that pupils with SEN were active and pleased to participate in an English language lecture, while $26.9 \%$ disagreed.

\subsubsection{Teacher engagement in the learning process of pupils with SEN}

A majority of pupils (74\%) stated that the teacher often distributed different assignments to pupils with SEN in English class. Moreover, most of the pupils (88.5\%) stated that the teacher always offered an explanation to SEN pupils if they asked for it. Furthermore, a great number of pupils (60.8\%) stated that they often worked in groups combined with pupils with different success in English, while only a small number of pupils (15.7\%) disagreed. The results can be seen below in Table 7 . 
Table 7. Teacher engagement in the learning process of pupils with SEN

\begin{tabular}{l|l|c|c|c|c}
\hline $\begin{array}{l}\text { ITEM } \\
\text { No. }\end{array}$ & QUESTION & $\mathbf{N}$ & $\begin{array}{c}\text { AGREE } \\
\text { (\%) }\end{array}$ & $\begin{array}{c}\text { PARTIALLY } \\
\text { AGREE (\%) }\end{array}$ & $\begin{array}{c}\text { DISAGREE } \\
\text { (\%) }\end{array}$ \\
\hline 4 & $\begin{array}{l}\text { The English teacher often gives different tasks } \\
\text { to students with disabilities. }\end{array}$ & 52 & 74 & 13.5 & 13.5 \\
\hline 13 & $\begin{array}{l}\text { When a student with special needs asks the } \\
\text { teacher for an explanation, the teacher always } \\
\text { explains it. }\end{array}$ & 52 & 88.5 & 11.5 & $/$ \\
\hline 18 & $\begin{array}{l}\text { We often work in groups in English classes } \\
\text { made up of students with varying degrees of } \\
\text { success. }\end{array}$ & 51 & 60.8 & 23.5 & 15.7 \\
\hline
\end{tabular}

\subsubsection{General attitudes of pupils towards pupils with SEN}

Pupils generally agreed that they liked learning English together with pupils with SEN, with the majority either agreeing or partially agreeing with this statement, while a small minority (32.1\%) disagreed with the statement. Most of the pupils (79.2\%) reported that pupils with SEN pupils did not disturb English lessons, while a considerably smaller number of pupils (7.5\%) agreed with this statement. Also, a great number of pupils (51\%) stated that they believed pupils with SEN understood the English lesson and could learn what was asked of them. Furthermore, $28.8 \%$ of pupils stated they considered that it might be better for pupils with SEN to learn English in other surroundings, $28 \%$ partially agreed, while a majority of $46.2 \%$ disagreed. The results are presented in Table 8.

Table 8. General attitudes of other pupils

\begin{tabular}{l|l|c|c|c|c}
\hline $\begin{array}{l}\text { ITEM } \\
\text { No. }\end{array}$ & QUESTION & $\mathbf{N}$ & $\begin{array}{c}\text { AGREE } \\
\text { (\%) }\end{array}$ & $\begin{array}{c}\text { PARTIALLY } \\
\text { AGREE (\%) }\end{array}$ & $\begin{array}{c}\text { DISAGREE } \\
\text { (\%) }\end{array}$ \\
\hline 7 & $\begin{array}{l}\text { I like learning English together with students } \\
\text { with special needs. }\end{array}$ & 53 & 37.7 & 30.2 & 32.1 \\
\hline 10 & $\begin{array}{l}\text { I think students with special needs understand } \\
\text { the material in English language classes and are } \\
\text { able to learn it. }\end{array}$ & 51 & 51 & 33.3 & 15.7 \\
\hline 11 & $\begin{array}{l}\text { Ithink it would be better for students with } \\
\text { special needs to learn English in a different } \\
\text { environment. }\end{array}$ & 52 & 28.8 & 25 & 46.2 \\
\hline 16 & $\begin{array}{l}\text { I think students with special needs often dis- } \\
\text { rupt the English lesson. }\end{array}$ & 53 & 7.5 & 13.2 & 79.2 \\
\hline
\end{tabular}




\subsubsection{Acceptance of pupils with SEN in the classroom}

Most of the pupils (73.6\%) stated that the class accepted pupils with SEN as a part of the classroom group, and $79.2 \%$ of them stated that they accepted SEN pupils as a part of the class. Moreover, a majority of pupils (77.4\%) stated that they tended to socialize with all the pupils in the class, regardless of their grades or success. Also, $52.8 \%$ of pupils agreed that they always cooperated with pupils with SEN during the English language lesson, while $37.7 \%$ of them agreed only partially. Furthermore, a great number of pupils (79.2\%) stated that they always offered their help to pupils with SEN, if needed. Additionally, $62.3 \%$ of the pupils disagreed with the statement that they would not take English courses with pupils with SEN if they could choose, while $20.8 \%$ of them agreed partially. Finally, a majority of the pupils (79.2\%) disagreed that pupils with SEN disturbed English lessons and that lessons might be more successful without them.

\section{DISCUSSION}

In the following section the results of the analyses with regard to each of the research questions will be discussed concurrently, including teacher attitudes toward teaching pupils with SEN, pupils with SEN attitudes toward learning English, and other pupils attitudes regarding SEN pupils in the EFLclassroom. The results of the analysis of the questionnaires have shown both similarities and differences in the responses between all the participants. The first theme dealt with the topic of inclusion in the learning process. When it came to the general question of inclusion of pupils with SEN in the learning process, all the participants agreed that SEN pupils were included in the EFL class. However, when it came to direct involvement in the classroom activities, a few differences emerged. The majority of teachers stated that they regularly called on pupils with SEN and included them in pair and group work, while SEN pupils were somewhat more divided on this issue. Meanwhile, other pupils did not seem to strongly believe that teachers asked pupils with SEN to participate in classroom talk, nor did they think that they were active during class. This suggests a discrepancy with regard to the issue of classroom participation for pupils with SEN among the various participants. A study carried out by Padurean (2014) found that among Romanian English L2 teachers there was a belief that students with SEN slowed the pace of the lesson and that students with SEN were less called upon due to time pressure to complete the curriculum. Although teachers in this study stated that they included SEN pupils 
in the lesson, it is possible that due to time pressure this actually happens less often than they believe.

Concerning teacher engagement in the learning process of pupils with SEN, teachers generally reported that they were actively engaged in the education of SEN pupils. They made an effort to encourage and motivate pupils with SEN, as well as present new material to them in the best possible way. They also stated that they encouraged other students to help them and generally supported inclusiveness in the EFL classroom. However, teachers were less in agreement about the introduction of new material and tasks for pupils with SEN, and there seemed to be somewhat less consensus about cooperation with parents. Bouillet (2013) suggested that teamwork in school, including cooperation with parents of children with SEN and teachers are important prerequisites for successful inclusion. However, in Croatian schools, this cooperation appears to be somewhat lacking as shown from the results of this study. Pupils with SEN agreed that teachers were helpful during the lesson and they could freely ask them questions. Similar to teachers' reports, SEN pupils also claimed that new or alternative tasks for them were not the norm. Other pupils agreed that teachers made an effort to answer SEN pupil questions. An interesting difference in attitudes was related to the question of the use of different tasks for SEN pupils whereby, in contrast to pupils with SEN and teachers, the majority of pupils agreed with this statement. One possible explanation for this difference could be related to the amount of workload given to pupils with SEN compared to regular students with the former being given fewer tasks. Again, it is most likely that due to time pressure, teachers lack the time to come up with new material and tasks for pupils with SEN.

Generally, it was found that the majority of teachers believed that the English program was too difficult for pupils with SEN. Moreover, a large number either agreed or partially agreed that they would be better off learning English in a different context; however, the majority supported the idea of inclusion which seems to be somewhat contradictory. Teachers were sympathetic toward pupils with SEN and were positive regarding their advancement. In addition, teachers' self-perceptions about their ability to teach pupils with SEN were high; nevertheless, a significant amount of teachers stated that it took them a lot of time and effort to create an appropriate plan and program for pupils with SEN. SEN pupils' attitudes towards English were positive, for example, a majority of them stated that they liked learning English in school and looked forward to the English lesson; moreover, they felt a great deal of personal satisfaction when suc- 
cessfully completing a task. Most pupils with SEN also reported that they understood the material and could follow the lesson. However, a third did acknowledge that the English program was too difficult for them. The majority were also against being put into smaller groups and separated from their class. Meanwhile, the attitudes of other pupils towards learning English in the same class as pupils with SEN were more divided even though most reported that they liked learning English together with pupils with SEN. This division emerged again when asked if pupils with SEN should be placed in a different surrounding, with more than half agreeing with this statement and a little less than half disagreeing. Other pupils did not agree that SEN pupils disrupted the class and the majority stated that pupils with SEN could follow the lesson. The results of this part of the questionnaire reveal some interesting results, especially with regard to the level of difficulty of the course program. It is possible that learner needs are not being met due to the level of difficulty facing pupils with SEN which brings into question the level of actual EFL attainment. Moreover, teachers again revealed that time constraints were a factor in developing an appropriate program for pupils with SEN. Furthermore, although both teachers and other pupils supported the inclusion of pupils with SEN in the class, there were some ambivalent feelings that need to be further explored.

When it comes to the acceptance of pupils with SEN in the classroom, positive attitudes seemed to prevail from the side of the teachers. A large majority of teachers stated that they accepted pupils with SEN as part of the class, they listened to their ideas and did not make differences between them and other pupils. However, a little over half of the teachers partially agreed with the statement that they would not choose to teach a class with SEN pupils suggesting some difficulties with the situation. On the other hand, the majority of the teachers disagreed with the statement that pupils with SEN disturbed English lessons and that they would rather not teach them. According to Skočić Mihić, Gabrić, and Bošković (2015) successful inclusion is not possible without competent teachers with positive attitudes which promote the values of inclusion. The results of this research suggest that teachers do perceive the benefits of inclusion. Pupils with SEN reported feeling largely accepted in the English class, although a third did report some hesitations. In addition, a large majority stated that they socialized with classmates which made them feel happy. Other pupils also reported positive attitudes and acceptance of classmates with SEN. They stated that they accepted pupils with SEN as part of the group, socialized with them, and tried to answer their questions during class. They once again re-iterat- 
ed that pupils with SEN did not disturb the class, and they confirmed that they worked with them. In a research conducted by Igrić and Žic (2001) the results showed negative attitudes towards acceptance of pupils with SEN among their classmates. The results of this study, on the other hand, showed mainly positive attitudes towards pupils with SEN on behalf of their peers. In addition, the attitudes of pupils with SEN regarding their acceptance in the classroom were also positive, which is in accordance with the study carried out by Igrić and Žic (2001). Moreover, a study conducted by Vican (2013) indicated that pupils from the region of Slavonia, including those who live in small towns, tended to perceive inclusion in a more positive way than pupils from large cities such as Zagreb. It was suggested that this might have been due to general feelings of connectedness and solidarity associated with small-town classrooms. This explanation may account for the generally positive attitudes towards pupils with SEN among pupils in this research which was conducted in smaller cities and villages in Slavonia.

Teacher attitudes towards their competency to teach pupils with SEN showed several interesting results. Namely, the majority of teachers only partially agreed with the statement concerning their competence to recognize the educational needs of pupils with SEN. Nevertheless, they were generally confident that they could teach heterogeneous classes. What is more, all the examined teachers reported the need for further education in the area of inclusion and dealing with pupils with intellectual difficulties. The results of previously conducted studies in Croatia are in accordance with the results of this study when it comes to teacher competency in dealing with pupils with SEN. Namely, Kiš and Glavaš (1998) concluded that there was a need for additional education among teachers concerning SEN pupils. Furthermore, teacher self-confidence and professional competence which are necessary conditions for successful inclusion were missing. Bouillet (2013) also suggested that teachers needed more support, specific advice, and concrete help in the education of pupils with SEN, which is also in accordance with the findings of this study.

\section{CONCLUSION}

Inclusive education has been included in various acts and regulations in Croatia; however, the actual application of inclusion is still in its development. This research attempted to focus on general attitudes towards inclusiveness in EFLteaching, while the results revealed several specific factors related to this issue. The results of this study showed mainly pos- 
itive attitudes towards inclusion on behalf of teachers, pupils with SEN, and other pupils. However, some contradictory attitudes did appear. For example, differences appeared with regard to perceptions of SEN pupils' participation in classroom activities. Both teachers and SEN pupils agreed that the introduction of new materials and tasks was somewhat lacking, whereas other pupils perceived this issue differently. Moreover, teachers were pleased with seeing their SEN pupils advance in their EFL class; nevertheless, the majority of teachers perceived the program to be too difficult for pupils with SEN and felt that they might benefit more in other learning contexts. In addition, the need to create a separate plan and program was considered time-consuming by teachers, and the majority of them felt they needed to be better trained to deal with the challenges of teaching children with learning difficulties. SEN pupils' attitudes towards learning the English language in schools were positive and were accompanied by feelings of acceptance in the learning process. Furthermore, most felt they could follow the program. Other pupils accepted pupils with SEN, but results showed ambivalence toward the idea that pupils with SEN should learn English in different contexts. In short, the results of this study show the need for the further education of language teachers dealing with pupils with SEN, as well as a re-examination of the ability of pupils with SEN to follow the EFL program. The limitations of this study include the relatively small number of participants and schools, suggesting a wider sample for future research. In addition, a longer Likert scale could have yielded better results in terms of analysis of average means. The results also suggest the need for further research in the practice of inclusion in Croatian schools, as well as improvement of existing inclusive education in the field of EFL learning in schools.

\section{REFERENCES}

Armstrong, T. (2012) Neurodiversity in the Classroom: Strength-Based Strategies to Help Students with Special Needs Succeed in School and Life. Alexandria, USA, ASCD.

Bendová P. \& Fialová A. (2015) Inclusive education of pupils with special educational needs in Czech Republic primary schools. Procredia - Social and Behavioral Sciences (171), 812819.

Bishaw, K.S. \& Javaprada, C.L. (2012) Inclusive Teaching in the Context of English Language Teaching (ELT). International Journal of Physical and Social Sciences, 2(11), 214-228.

Borić, S. \& Tomić, R. (2012) Stavovi nastavnika osnovnih škola o inkluziji. Metodički obzori, 7(3), 75-86.

Bouillet, D. (2013) Some Aspects of Collaboration in Inclusive Education - Teachers' Experiences. CEPS Journal, 3(2), 93-115. 
Bukvić, Z. (2014) Teachers competency for inclusive education. The European Journal of Social and Behavioural Sciences. 1585-1590.

Dmitrović, P. (2011) Preduvjeti za primjenu inkluzije. Metodički obzori 6(3), 69-82.

European Commission. (2005) Special Eductional Needs in Europe: The Teaching and Learning of Languages. Finland: Insight\&Innovation.

Friend, M. \& Bursick, W.D. (2012) Including Students with Special Needs: A Practical Guide for Classroom Teachers. New Jersey, Pearson Education, Inc.

Hodkinson, A. (2010) Inclusive and special education in the English educational system: historical perspectives, recent developments and future challenges. British Journal of Special Education 37(2), 61-67.

Igrić, Lj. (2003) Društveni kontekst, posebne potrebe / invaliditet / teškoće u razvoju i edukacijsko uključivanje. Hrvatska revija za rehabilitacijska istraživanja 40(2), 151-164.

Igrić, Lj., Wagner Jakab, A. \& Cvitković, D. (2012) Samoprocjena i procjena ponašanja učenika s teškoćama u redovnoj osnovnoj školi. Hrvatska revija za rehabilitacijska istraživanja, 48(1), 1-10.

Kiš-Glavaš, L., Nikolić B. \& Igrić Lj. (1997) Stavovi učitelja prema integraciji učenika usporenog kognitivnog razvoja. Hrvatska revija za rehabilitacijska istraživanja, 33(1), 63-75.

Kudek Mirošević J. (2007) Inclusive education in Croatia; Regional Workshop - Europe on Inclusive Education. Sinaia, Romania: UNESCO.

Marsh, D. (2005) Special Educational Needs in Europe: The Teaching \& Learning of Languages. Finland, European Comission. <http://tictc.cti.gr/documents/doc647_en.pdf >.

McColl, H. (2005) Foreign Language Learning and Inclusion: Who? Why? What? - and How? Support for Learning, 20(3), 103-108.

Ministarstvo znanosti, obrazovanja i sporta. (2017) Zakon o odgoju i obrazovanju u osnovnoj i srednjoj školi. Narodne novine, Zagreb.

Oraganization for economic co-operation and development (OECD) - Starting strong. (2007). Synthesis report and Chapter 3 Croatia in Education Policies for Students at Risk and those with Disabilities in South Eastern Europe: Bosnia-Herzegovina, Bulgaria, Croatia, Kosovo, FYR of Macedonia, Moldova, Montenegro, Romania and Serbia. Paris.

Padurean, A.N. (2014) Teaching English Language to Children with Special Educational Needs. TEM Journal, 3(4), 309-314.

Skočić Mihić S., Gabrić I. \& Bošković S. (2016) Učiteljska uvjerenja o vrijednostima inkluzivnog obrazovanja. Hrvatska revija za rehabilitacijska istraživanja 52(1), 30-41.

Smith, A.M. (2006) Inclusion in English Language: Teacher Training and Education. Lancaster University, UK.

UNESCO (1994). The Salamanca Statement and Framework on Special Needs Education, in Salamanca, Spain (7-10 June 1994), Paris: Unesco.Vican D. (2013) Inkluzivna kultura osnovnih škola u Hrvatskoj s gledišta učenika. Život i škola, 59(30), 17-37.

Vican D. \& Karamatić Brčić M. (2013) Obrazovna inkluzija u kontekstu svjetskih i nacionalnih obrazovnih politika. Život i škola, 59(30), 48-66.

Watkins, A. (Ed.) (2009). Key Principles for Promoting Quality in Inclusive Education: Recommendations for Policy Makers. Odense, Denmark: European Agency for Development in Special Needs Education.

Žic, A., \& Igrić, Lj. (2001) Self-assessment of relationships with peers in children with intellectual disability. Journal of Intellectual Disability Research, 45(3), 202-211. 


\title{
Inkluzivno obrazovanje u nastavi engleskog jezika
}

\author{
Rina Benko \\ rina.slivar@gmail.com \\ Osnovna škola Matije Petra Katančića, Valpovo
}

\author{
Anna Martinović \\ amartino@unizd.hr \\ Sveučilište u Zadru
}

\begin{abstract}
Ovaj rad prikazuje inkluzivno obrazovanje u nastavi engleskog jezika. Cilj ovoga rada jest prikazati stavove nastavnika engleskog jezika u hrvatskim osnovnim školama prema učenicima s posebnim potrebama, stavove učenika s intelektualnim teškoćama prema nastavi engleskog jezika te stavove ostalih učenika u razredu prema učenicima s posebnim obrazovnim potrebama. Istraživanje se temelji na upitniku koji je uzet iz prijašnjih studija provedenih u Hrvatskoj i Europi. Iz rezultata istraživanja može se zaključiti da među nastavnicima ne prevladavaju negativni stavovi prema učenicima s intelektualnim teškoćama. Ipak, evidentno je da je nastavnicima engleskog jezika neophodno usavršavanje u području specijalnog obrazovanja, jer je većina nastavnika izrazila potrebu za dodatnim kompetencijama i obrazovanjem u tom području za rad s učenicima s posebnim potrebama.
\end{abstract}

Ključne riječi: inkluzivno obrazovanje, nastava engleskog jezika, stavovi 